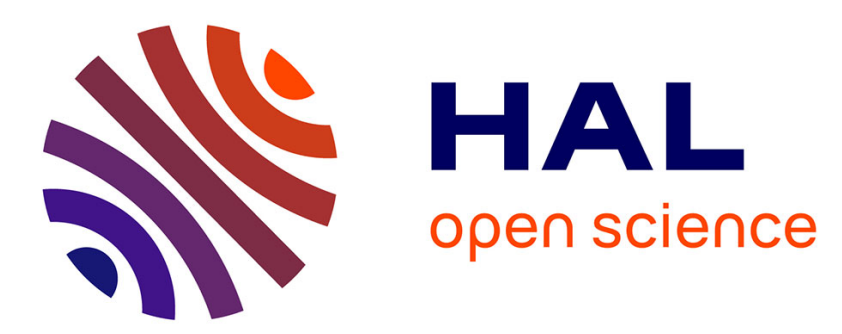

\title{
The Indexical Reordering of Language in Times of Crisis: Nation, Region, and the Rebranding of Place in Shetland and Western Ireland \\ Sara C Brennan, James Costa
}

\section{- To cite this version:}

Sara C Brennan, James Costa. The Indexical Reordering of Language in Times of Crisis: Nation, Region, and the Rebranding of Place in Shetland and Western Ireland. Signs and Society, 2016, 4, $10.1086 / 684680$. halshs-01413317

\section{HAL Id: halshs-01413317 \\ https://shs.hal.science/halshs-01413317}

Submitted on 9 Dec 2016

HAL is a multi-disciplinary open access archive for the deposit and dissemination of scientific research documents, whether they are published or not. The documents may come from teaching and research institutions in France or abroad, or from public or private research centers.
L'archive ouverte pluridisciplinaire HAL, est destinée au dépôt et à la diffusion de documents scientifiques de niveau recherche, publiés ou non, émanant des établissements d'enseignement et de recherche français ou étrangers, des laboratoires publics ou privés. 


\title{
The Indexical Reordering of Language in Times of Crisis: Nation, Region and the Rebranding of Place in Shetland and Western Ireland
}

\author{
Sara C. Brennan, Heriot-Watt University, Scotland \\ James Costa Wilson, Centre for Multilingualism in Society, University of Oslo, Norway
}

\begin{abstract}
This article analyzes how under conditions of crisis certain social actors shift the metasemiotic frames through which minority languages may be approached in order to suit place-branding purposes and to make them more widely accessible for business usage. In the cases we investigate in Shetland and Western Ireland, the new meanings associated with language are connected with how crises are framed and constructed in discourse. We thus examine two types of crises in which certain social actors view language as part of the solution to ward off specific trouble: posteconomic meltdown (Ireland) and depopulation (Shetland). With the branding potential of these languages then positioned as part of the solutions to "crises," new indexical alignments exemplify the neoliberal metasemiotic framework through which all elements of social and cultural life may be strategically made marketable - in this case on the intra- and international markets on which people themselves are vied for.
\end{abstract}

he current ways in which crises are dealt with in late capitalist societies date to the gradual establishment of so-called neoliberal (or monetarist) regimes in the 1970s partly as a consequence of the interpretation of the

This article grew out of a joint presentation given at a conference organized under the aegis of COST Action IS1306: "New Speakers in a Multilingual Europe-Opportunities and Challenges." This work was partly supported by the Research Council of Norway through its Centers of Excellence funding scheme, project numbers 223265 and 213831, as well as by COST Action IS1306. Author names are in alphabetical order.

Contact Sara C. Brennan at Languages and Intercultural Studies, Heriot-Watt University, Henry Prais Bldg., EH14 4AS, Edinburgh, Scotland (scb31@hw.ac.uk), James Costa Wilson at ILPGA, Sorbonne Nouvelle, 19 rue des Bernardins, 75005 Paris, France (james.costa@icloud.com).

Signs and Society, vol. 4, no. S1 (Supplement 2015). ( 2015 Semiosis Research Center at Hankuk University of Foreign Studies. All rights reserved. 2326-4489/2015/04S1-00XX\$10.00 
economic crisis that had started earlier in that decade as a perceived failure of Keynesian models. Western societies have been construed as undergoing a state of continuous crisis since then, thus enabling governments to implement a particular agenda involving, inter alia, the deregulation of labor markets and, crucially for this article, the gradual subjection of all areas of social and cultural life to the logic and conditions of the market economy (Rossiter 2003; Harvey 2005; Urciuoli and LaDousa 2013). Place branding can be viewed both as a response to increasing conditions of competition and as a way to engage effectively in those dynamics (van Ham 2008; Aronczyk 2013). The very capacity to influence the decisions of tourists, potential newcomers, and other capital-wielding social actors is the weapon of choice of nation branding, which itself has emerged as an internally prominent practice in relation to another "crisis" - that of nationstates ceding power to neoliberal markets.

\section{Crises and Neoliberalism}

This article analyses how the construction of particular moments as "crises" can generate changes in how the indexical order in which language is inscribed may be modified to fit new dynamics and interests. "Crises" are sets of events grouped together to call on, justify, and legitimize certain types of changes. In traditional Marxist analyses they are viewed as inherent to the dynamics of capitalism, and more recently analysts such as Naomi Klein have argued that neoliberal economic and political regimes have relied on crises, sometimes purposely generating them, to impose "shock and awe" types of neoliberal regulations in response (Klein 2008). Crises are crucibles in which various types of local events are reinterpreted according to more widely circulating frames in order to prompt and legitimize certain action as inevitable. They rely on the mobilization of (apparently) new scales - that is, levels of framing (Blommaert 2007) — to reshape a given indexical order (the constellation of potential meanings ideologically permitted under a given set of social and historical conditions (Silverstein 2003; Eckert 2008)). In order to illustrate the explanatory potential of crises as moments of semiotic reordering, our article focuses on two different types of frames invoked to construct crises: demography in Shetland (northern Scotland) and the economy in Western Ireland.

The term crisis is itself deceptive for at least two reasons. First, it posits the existence of an otherwise stable - or normal (Roitman 2013) - time that predated the crisis and will return as a result of a number of policies implemented against it. Crises are therefore more productively studied as emic categories generated by people to act on a situation and to legitimize certain types of ac- 
tion. For some, the crisis will warrant more measures aligned with aspects of the neoliberal paradigm; for others, it will prompt the need for a radically new order.

Second, framing a concern in terms of "economic" or "demographic" crisis draws attention to those factors and obliterates others that might have brought the current situation into being. Indeed, the sociologist Michel Wieviorka considers that in a so-called economic crisis, the sources are not to be found in the economic domain but in more general cultural, social, and political dynamics (2009, 189).

Crises are thus best understood as historical and ideological moments, viewed by the actors involved as unstable and transformative and used to assess a situation in terms of diagnosis and remedy in order to justify certain types of action. During these processes, a number of elements are ascribed (new or renewed) indexical value to justify and implement action. But crises are also themselves a sign of those transformations, and the term itself can thus be approached as a sign indexing a number of ideological and regimental changes in a context defined by its involvement in the crisis. A general question that arises is, therefore, How are crises characterized in semiotic terms? Which elements are indexically reordered, by whom, and to what effect? More specifically, we are interested in language as a mobilizable set of signs under conditions of crisis. Our work results from several years of involvement and fieldwork in Scotland and Ireland and is rooted in a critical sociolinguistic paradigm (Heller 2011). In that respect, we focus on "what actors do with linguistic resources that circulate through social spheres and social networks" (Heller 2011), examining both how social actors mobilize signs associated with language within other social actions and how this mobilization modifies views on language and its role within the new semiotic order. Consequently, we ask how traditional indexical orders implied by older regimes of language are being (re)shaped in order for signs to be appropriated and used by new types of users in a way that grants them authority to do so.

\section{Branding the Nation (or Parts of It) in Neoliberal Regimes}

If crisis can be viewed as a set of signs mobilized to promote neoliberal types of responses, the maximized market freedom and minimized state intervention of neoliberalism itself can also be constructed as a crisis for the modern nation-state. Crisis has in turn, in many cases (including in Scotland and Ireland), legitimated recourse to different types of responses, among them nation branding. 
As the scope of markets in late capitalism has expanded and transcended national boundaries, nation-states have lost some of the authority they previously possessed over the production, consumption, and circulation of goods, services, social actors, and discourses (Heller 2008; Heller 2011; Duchêne and Heller 2012). Nation-states are thus now in direct competition with sub-, inter-, and transnational entities and organizations for "political authority and loyalty in a dense and highly competitive market, embarking upon a quest for the hearts and minds of people both at home and around the world" (van Ham 2008, 128).

In this quest, states have increasingly sought to strategically rearticulate and reassert the relevance of nation and nationhood through place branding. Unlike place marketing, which aims to promote and sell a place as an assemblage of products or services (Lucarelli and Brorström 2013, 66), place branding instead draws on the tenets of branding to establish an affective relationship between consumer and brand - in this case, between (potential) residents, tourists, and so on, and place brand. By fostering the development of this social attachment, branding allows consumers to engage in the production of meaning and value-or even to "choose lives" (Fournier 1998, 367)-through their relationship to brands (Prahalad and Ramaswamy 2004; Nakassis 2012). The goal of nation branding in particular is thus to insist on the meaningfulness of the nation for existing or prospective citizens, tourists, and investors alike: "In short, the goal of nation branding is to make the nation matter in a world where borders and boundaries appear increasingly obsolete" (Aronczyk 2013).

Among the markets on which nation branding attempts to make the nation matter, the most commonly referred to is tourism - it should, however, only be envisaged as one particular instantiation of the transformation of people themselves into an object of competition. Whether temporary (tourism) or permanent (migration) mobilities are at stake, they are always embedded in individual and collective projects that aim to influence some people's (and not others') destination or place of residency. Under conditions of crisis, the capacity to influence people's judgment becomes crucial for the very survival of territories, whether the chosen strategy involves promoting a given territory as a touristic destination to counterbalance the effects of an economic crisis by boosting local revenue and employment or depicting it as a desirable place of dwelling to attract new residents in the case of a demographic crisis.

Nation branding features heavily in the national strategies for international positioning elaborated in both Scotland and Ireland, particularly in attempts 
to appeal to those considered to constitute their respective national diasporas (Brennan and Costa 2013). In both countries, nation branding can be seen as an attempt to attach new indexical properties to territories or to redefine older ones, with the aim of generating added value on a number of markets such as culture, tourism or other economic markets (Del Percio 2013, 155). However, while "multiple and contested imaginations of the nation are possible" (Dzenovska 2005, 174), nation brands are shaped by and project the situated interests of certain social actors in positions of power at a given moment and thus "narrowly circumscribe national imaginaries" (Kaneva and Popescu 2011). Recognizing the selective and strategic mobilization of signs in the branding of nations, this article addresses the issue of place branding within the nation when local interests find themselves at odds with the national strategy or when one particular element - here language - is for whatever reason left out of the national strategy and yet remains an important resource for local strategies. In that respect, places compete not only internationally but also within the nation, here within Scotland (and the United Kingdom) and Ireland.

\section{Research Sites and Fieldwork}

Specifically, we address new meanings assigned to language in place branding strategies in Shetland and Western Ireland. Shetland is an archipelago off the north coast of Scotland, situated between the Scottish mainland and the western coast of Norway. Its position as an important center for North Sea oil exploitation shielded it from the post-2008 economic meltdown: unemployment rates, for example, have consistently remained lower than 2 percent throughout the entire period (Shetland Islands Council 2012). The main issue on Shetland is demographic rather than economic, with the Shetland Islands Council investing heavily in infrastructure and branding to attract new inhabitants and to avert the specter of depopulation, the consequences of which are felt across many rural areas throughout Europe.

Costa has been conducting on-and-off fieldwork in Shetland since 2013 as part of an ongoing project financed by the Norwegian Research Council on standardization as a linguistic regime in Scotland. His fieldwork has mainly involved conducting observations and informal interviews among dialect advocates and local businesses who rely on the idea that the production of authentically Shetlandic products (i.e., somehow linked to Shetland as an identifiable place) has the potential to sustain economic activity. For this article, we rely on data generated through both observation and a two-hour interview 
with employees of the Shetland Brand organization and on informal interviews and contacts with businesses participating in the Shetland Craft Trail. ${ }^{1}$ Participants in this scheme involve both native Shetlanders and newcomers who sought to draw on the islands' reputation and natural resources to establish businesses.

Western Ireland, meanwhile, has along with the rest of the Republic of Ireland weathered the course of the 2008 Irish financial crisis and the ensuing severe economic recession and dramatic rise in unemployment. The issue in Western Ireland is thus economic, with tourism - "the single most important industry in the west of Ireland" (Anderson, Bakir, and Wickens 2015, 78) widely positioned as "one of the sectors that can aid increased local employment, revenue generation and social capital thus lifting local, regional and national economies" (Gorman and Mottiar 2015, 142).

Brennan has been conducting fieldwork in Western Ireland since 2011, first as part of her MA thesis at the University of Lyon (France) and then as part of $\mathrm{PhD}$ research at Heriot-Watt University in Edinburgh (Scotland). Through observation, semistructured interviews and informal interactions, her fieldwork has focused on community-level Irish-language advocacy organizations and the members of the local urban private sectors that these organizations seek to influence through specifically business-centered initiatives that promote Irish as an economically valuable commercial resource. In this article, we draw primarily on data generated during multiple meetings with the development officer of one such Irish advocacy organization (Baile Rua le Gaeilge), as well as with the member of the organization who is spearheading their Irishin-business initiative. The organization's website and the promotional materials (e.g., pamphlets, posters, stickers) that its members distribute to local businesses also figure into our analyses.

In both areas, a sense of crisis is wrought into a narrative that both informs and justifies the need to brand territory and to make it appealing to a group of "others"-also defined in that very same process. In Shetland, these others are not only tourists but also young adults willing to set up businesses locally and to raise families. In Ireland, they include both international tourists and domestic visitors, particularly the latter in Western Ireland. In both cases, nevertheless, new configurations allow for the redefinition of what counts as authentically local and autochthonous and of who has authority over defining "the local."

1. This initiative is detailed at http://shetlandartsandcrafts.co.uk. 
In the next sections we analyze those crises, turning first to Shetland and then to Ireland. We focus in both cases on how signs are mobilized to address such perceived moments of societal stress.

\section{Land, Sea and Images of Scandinavia in Shetland: Branding Authenticity and Making It Available to Newcomers}

Shetland is in many ways unusual with regard to European peripheries. Its location in the North Atlantic Ocean between Scotland and Norway clearly marks it as a peripheral region in contemporary Europe. Historically however, this location made the islands central to fishing and commercial routes. To this day, it does not fit the usual model of economic decay and decline leading to an overreliance on tourism as its main industry, as is the case in Scotland's western islands or Ireland's western periphery (see Pietikäinen and Kelly-Holmes 2013). According to historian Lynn Abrams, "Shetland . . . has avoided the fate of many of Europe's peripheral regions - that of dependency on the centre - on account of its ability to maintain its position in the fishing industry . . . and because of the benefits accrued from oil" (Abrams 2005, 13). The oil industry has been a significant contributor to Shetland's growth since the 1970s, when exploitation began in the North Sea. While the discovery of oil initially sparked fears that Shetland's culture might gradually disintegrate, the local authority (the Shetland Islands Council [SIC]) managed to secure additional powers as well as a substantial income from that industry, allowing it to develop cultural initiatives such as museums and a well-funded archives center.

The islands' relative remoteness, however, makes them acutely vulnerable in terms of population fluctuations. ${ }^{2}$ Despite its influence on the economy, the oil industry relies primarily on temporary workers from other parts of the world, such as England, Ireland, or the Middle East, accommodated on floating barges in different locations around the islands. Although up to three thousand temporary workers can reside on the islands at any given time, the permanent population of the islands is approximately 23,000, up from 17,245 in 1966 but down from around 30,000 at the end of the nineteenth century (Thomson 1983, 151). In order to secure its existence as a viable human community, Shetland needs, in the words of the SIC, to attract people - not merely tourists, but crucially new permanent residents. While this is obviously an issue for most European peripheries, Shetland differs in that its wealth allows the insular Council to commission the development of strategies to increase its popu-

2. It takes one hour to fly from mainland Scotland to Shetland's main airport or twelve hours to reach Lerwick, the archipelago's capital, from the Scottish port of Aberdeen by ferry. 
lation. One such strategy was formulated by London-based consultants at the turn of the twenty-first century and was framed in terms of branding based on what was termed "authenticity."

It is this strategy, and more specifically the role assigned to language, that we wish to understand in this section. Language is by no means a priority, but, as the vernacular is largely spoken locally, parts of it can be mobilized as potent indexes of locality and distinction. First, however, we analyze the ideological climate in which the use of Shetland's vernacular was rendered possible at all, in the form of a short detour via nineteenth-century Scottish, imperial, and Victorian racial politics. We show how, together, they construct a chronotope connected with a particular view of Shetland under Scandinavian rule in the Middle Ages, before analyzing how language is promoted in Shetland as an index of this chronotope.

\section{Determining Mobilizable Signs of Authentic Shetlandness}

The marketization of Shetland classically relies on the mobilization of a number of previously circulating tropes, images and ideas that can be joined together and made available for branding purposes (Nakassis 2012). This process depends on the rhematization and erasure (Gal 2005) of a number of social processes at play in the history of the islands since the early nineteenth century. In this section we show how language was made available for such purposes by focusing in particular on the Scandinavian elements of the Shetland vernacular, known locally as Shaetlan or in the linguistic and anthropological literature as Shetland Scots, Shetlandic, or the Shetland dialect. This Scandinavian legacy is generally understood to be a consequence of the occupation of Shetland by Norway and Denmark in the Middle Ages until the archipelago was pawned to Scotland in 1468 and 1469 (Crawford 1969; Barnes 1998).

According to the 2011 Census in Scotland and despite a generally lowly status for most of the twentieth century, ${ }^{3}$ over 40 percent of the population of Shetland speaks Shetlandic. ${ }^{4}$ Let us provide an example of a representative text in Shetlandic as it is spoken in contemporary Shetland to illustrate the distance between Shetlandic and (Standard) English. It is taken from a novel by

3. The following quote from 1986 displayed at the Shetland Museum in Lerwick echoes the common indexical order that linked nonstandard languages with backwardness and rudeness in the British standard language ideology: "To speak in a Shetland accent in school would have been absolutely forbidden. It would have been regarded as rudeness" (John Manson, 1986).

4. See the national census website for Scotland at http://www.scotlandscensus.gov.uk/ods-web/datavis.jsp ?theme $=$ Language_September_2013. 
John Graham, Shadowed Valley, ${ }^{5}$ published in 1987 and featured on the website of the Shetland dialect promotion organization Shetland Forwirds (Shetland forward):

I ken wir ahint wi wir rent but I dunna hae a penny i da hoose. Seemon'll be hame noo ida Hairst an he'll pay Mr Ogilvy what he can manage fae his whale-money.

[I know we're behind with our rent but I don't have a penny in the house.

Simon will be home in the autumn and he'll pay Mr. Ogilvy what he can manage from his whale money.]

The metasemiotic frames through which language in Shetland is still widely interpreted owe much to the dynamics put into place during the nineteenth and twentieth centuries. Modern Shetland was put on the map for the educated Scottish public in 1822 after Sir Walter Scott published The Pirate, a novel based on a Romantic vision of contact between Scots and native Shetlanders in the early modern era that functioned as a glorification of the islands' Scandinavian past (Cohen 1983; Mortensen 2000). But it was the political utility of Anglo-Saxon and Germanic ancestry in Victorian times that provided the ideological baggage that made Vikingness - and Shetland - useful not only locally but also more widely in Britain. Germanic peoples, and among them Scandinavians, were thought of as embodying the values that Liberals sought to promote: personal initiative, risk taking, and a natural taste for democracy, individual, and constitutional freedom (Cohen 1983; Hammond 2006). Shetland's past fit perfectly into the Liberal narrative and agenda of the times in Scotland and more generally in Britain.

The view of the vernacular as one of the components of this Scandinavian heritage and as a mobilizable resource is thus a product of late nineteenthcentury antiquarian and philological work. Antiquarians and philologists proposed a new semiotic order under which signs of Norseness could be viewed as a source of pride rather than of shame, as had been the case throughout the eighteenth century (Cohen 1983). But they were interested in documenting the local vernacular not for its intrinsic merits but for its value as a repository of the ultimate traces of Scandinavian presence - thought to rest in its vocabulary. At least three scholars undertook the task of looking for the remains of Norn (as the Scandinavian language of the islands—-spoken until the 1750s [Barnes

5. John Graham is also the author of a Shetland dictionary (1979) and grammar. A recording of this extract is also available from the Shetland Forwirds website, http://www.shetlanddialect.org.uk/shadowed-valley. 
1998] — was known) from the second half of the nineteenth century onward. Among them, the Faroese philologist Jakob Jakobsen is undoubtedly the most renowned.

At the end of the nineteenth century in Shetland, Jakob Jakobsen spent many years collecting the last remnants of Norn. The result was a monumental Etymological Dictionary of the Norn Language in Shetland published in Danish (1908-1921) and subsequently in English (1928-1932). In those volumes he drew particularly on the Scandinavian aspects of language in Shetland, focusing on etymology and inventorying Norn words. Like other scholars before him, he referred to the Shetland vernacular only as "dialect." To this day this achievement remains a major source of linguistic and cultural reference in Shetland and Scandinavia. Crucially, Jakobsen, a committed pacifist, also propagated the idea of the Viking colonists as the forebears of egalitarianism and democracy, thereby consolidating the positive associations between Shetland and Scandinavia through linguistic work

Philological work in Shetland, and Jakobsen's in particular, certainly helped extoll the status of things Scandinavian. It promoted the idea of the local vernacular as a dialect whose value derived mostly from its being a repository for the islands' Scandinavian heritage rather than from its being a distinct language in its own right.

Throughout the twentieth century, the Norse heritage was constantly referred to with more or less emphasis. This was the case particularly in the New Shetlander, a cultural and political magazine founded in 1947 by Peter Jamieson, a member of the Communist Party of Great Britain. The magazine was particularly interested in political issues, especially in the domain of agriculture and economic development. In that context, Faroese, Norwegian, and Icelandic politics in particular were scrutinized, cultural exchanges were organized, and over time literature was translated from the Scandinavian languages into Shetlandic, and vice versa.

The genealogy sketched above was fundamental to the definition of what counted as legitimate knowledge regarding language in Shetland throughout the twentieth century (see Nihtinen 2011). One late legacy of this trend is the recent publication of a new dictionary (Christie-Johnston and Christie-Johnston 2010) that makes salient the words of purportedly Norse origin by presenting them in blue ink.

The Scandinavianness of Shetland is an important component in the construction of Shetland as distinct from the Scottish mainland on several levelsfor tourism, and also as a way to justify claims for more powers to be devolved 
from Edinburgh to Shetland and to promote a sense of difference or distinction. In the 2014 referendum on Scottish independence, Shetlanders positioned themselves unequivocally against independence and emphasized the islands' distinctiveness throughout the campaign. Language, in this respect, also plays an important part in the assertion of Shetland's distinctive character, as the local Member of Scottish Parliament Tavish Scott illustrated during the referendum debates. In a response to the then Scottish First Minister Alex Salmond's claim that the oil industry would generate $£ 48$ billion in tax revenue until 2019, Scott declared: "It's no [not] your oil Alex, it's wirs [ours]" (Shetland News, March 12, 2013).

The processes of Scandinavianization initiated with the rhematization of the Norse element in Shetland generated two interrelated sets of consequences with respect to language. First, the Nordic or Scandinavian element of the language came to be hypervalued, and the ghost of Norn still haunts most discussions on language in Shetland. Second, the vernacular was constructed as a dialect rather than as a language in its own right. Even though Shetlandic is no longer generally viewed as inferior by its speakers, the regimentation of speech as dialect rather than as language has had far-reaching consequences in terms of how the vernacular is discussed, considered, and policed to this day. In particular, this regime equates dialect with inherited practices and tends to locate ownership within a framework of autochthony. It construes dialect as something that is acquired in the home rather than learned-for example, through books. It is indeed an oft-repeated trope on the islands that the dialect cannot be learned (despite the fact that a few counterexamples exist), and there are no teach-yourself books. Consequently, it cannot seriously be considered for public policy in the current Western European ideological framework that requires standardization for such purposes. On the other hand however, this regime frames dialect as existing on a continuum with (Standard) English, thus opening the way for emblematic usages within otherwise Standard English practices and usages. These discourses of dialect as well as those of Scandinavianness were drawn on by the "Shetland Brand" to conduct their mission. This is the object of the next section.

\section{The Shetland Brand}

In the 1990s, based on the hypothesis that oil might cease providing for the islands' main source of income within one generation, the SIC sought to invest in a more diversified future, in particular through the establishment of a Shetland Amenity Trust to promote Shetland worldwide. As the Trust website states, 
"Shetland Amenity Trust is contracted by Shetland Islands Council to promote Shetland to the world. The team at Promote Shetland are tasked with this role, directed by the main strategic objective to project Shetland on the world stage as an authentic, creative and highly desirable place to visit, live, study or do business with." 6

The Promote Shetland initiatives as well as the Shetland Brand that this article analyzes are funded by the council through the Shetland Amenity Trust. Although other Scottish regions share similar concerns for their future, in particular in terms of population, Shetland was able, economically and institutionally, to implement its own strategies. One such strategy was the commissioning of a branding strategy in 2002 from a London- and Bahrain-based branding consultant, Corporate Edge - a contract worth $€ 160,000$ (Grydehøj 2008). The main objective proposed by Corporate Edge was to move Shetland away from the risk of being perceived as a "pre-modern society: simple, admirable but lost in a time warp." Instead, it was to be constructed as "a small, clever country," similar in that respect to Ireland, for instance - an example provided in the document produced by Corporate Edge (Promote Shetland 2011). The Shetland Brand initiative was a direct consequence of this report. It ceased to exist shortly after I started conducting fieldwork, but its work is now continued by the umbrella organization Promote Shetland. The strategy devised by the SIC and based on the Corporate Edge report is summarized in a document published by this organization and titled The Shetland Marketing Strategy (Promote Shetland 2011).

During a meeting in May 2014, the three Shetland Brand permanent staff members emphasized their mission to promote Shetland as a viable and enviable destination to move to (as two of the three employees had done) and in which to set up businesses. Their task was to address Shetland's image in a way that would reflect its distinctive cultural and natural features, something that the general branding strategies for Scotland at large were unable to do-as they put it, there are no kilts or bagpipes in Shetland. The archipelago thus required its own development strategy, and the Shetland Brand was set up with the specific objective of facilitating the installation of newcomers on the islands.

In the Corporate Edge report as in the Shetland Brand strategy, authenticity ranked among Shetland's main assets. Promote Shetland defined authenticity mainly in terms of place and origin as located outside the individual. Within

6. See http://www.shetlandamenity.org/promote-shetland. 
this framework, place has agency and can confer by and of itself authenticity on certain goods or services under certain conditions, with "authentic" referring to the process of (at least partial) production on Shetland. The links with the islands, under those conditions, are achieved in terms of either local sourcing or production. Authenticity must be approached as a type of added value that is attached to a commodity through a particular operation conducted locally. Conferring authenticity thus amounts to an act of social magic that confers certain properties on particular commodities and attaches some of the properties ascribed to Shetland onto them, delimiting a before and an after (Bourdieu 1982). Locality is key to understanding who the right people to conduct such operations are, as well as the conditions under which they operate.

The question arises, therefore, whether newcomers can be expected to appropriate Shetland's authenticity to their own advantage - in other words, how they may mobilize signs otherwise attached to traditional inhabitants by virtue of their inherent connection with place. With this question in mind, we ask how the local Shetland vernacular can serve both as an index of authenticity and as a reservoir of signs that all, locals or newcomers alike, may tap into for their own undertakings. The following sections will examine what signs are mobilized in the face of demographic crisis, how they draw on an array of signs made available through historical and philological discourses to generate a sense of distinction through authenticity, and, finally, how those signs are made available to the expected newcomers.

\section{The Quest for the "Successful Idealists"}

In the competition to attract new residents, not all people are similarly valued. An important distinction must be made between pensioners, on the one hand, and young adults or couples, on the other (see also Etrillard 2015), the latter being more desirable from a long-term business and community development perspective. Promote Shetland indeed identifies young people as key to islands' future:

The paradox of a slowly declining population in a thriving economy with very low unemployment and relatively high average income did not escape our respondents. Although in-migration by an older age-group or associated with the [oil and gas] project under way at Sullom Voe may be temporarily reversing that trend, the challenge is to attract younger people to live in the islands, and hold on to more young local people or attract them back as graduates. This must depend on the creation of employ- 
ment and on offering an outstanding quality of life. (Promote Shetland 2011, 28)

This (partly new) population should then be able to cater to the islands' customer target, which the same document calls "successful idealists" — that is, people with both high economic and cultural capital:

"Successful" in this context means affluent, reflected in this group's ability willingly to pay a premium for things that are authentic and of fine quality. Their idealism is seen in the way that they seek genuine experiences, crafts or food. They are inclined to avoid the artificial or pretentious and are very much concerned about the origin of what they buy, how it was produced and by whom. They are likely to be strongly interested in (for example) the heritage, local arts, crafts and traditions, animal welfare, environmental issues and the use of additives. If they're buying Shetland lamb in London or ordering Shetland mussels in Paris, they'll be keen to know the story of the product. Although the parallel isn't exact, they're likely to share many attitudes with the now widelyused category of "ethical consumers." (Promote Shetland 2011)

In turn, those customers determine what behavior new residents should adopt, in particular with respect to the use of authenticity through locality:

When successful idealists choose to visit Shetland, they'll want an honest, personal experience of the islands rather than invented "visitor attractions." Eating out, they'll be more impressed by well-cooked, nicely presented local fish, lamb, beef or vegetables than by anything grandiose or imported. They don't want gold-plated taps but they do want good, friendly, intelligent service. (Promote Shetland 2011)

Within this framework, heritage is an essential source of distinction-to be achieved through a branding strategy that builds on a subtle balance of signs in order to make them widely acceptable and usable. This is the object of our next section.

\section{Transferring Authenticity and Its Legitimate Usage to Newcomers}

In this section we address the particular role of dialect as an example of how legitimacy is transferred to newcomers in the Shetland Brand strategy. As emphasized by the employees of Shetland Brand, dialect featured as an important part of the strategy. They also, however, mobilized frames that potentially op- 
posed dialect and the diversity of personal backgrounds on the islands, and they tended to reduce "dialect" to a mere set of words.

As a category, "dialect" is ambiguous at best: in the English-speaking world it summons subordination to Standard English as well as implications that it cannot be learned unless one was born with it, so to speak. A dialect course ran for several years on the islands and attracted a great deal of interest; notably, however, it emphasized knowledge about the dialect and included no communicative practices. How, then, can dialect - a key aspect of Shetland life - be used legitimately by newcomers? In particular, how accessible is it as an authenticity marker turned resource? In this section we identify two steps through which this is achieved in the Shetland Brand strategy. The first step recasts authenticity, and the second repositions Shetland as Scandinavia-in-Britain on its main market, the United Kingdom (which, according to the Shetland Brand director, accounts for 75 percent of Shetland's business activity).

First, then, what may or may not count as authentic, and, crucially, how? The Shetland Marketing Strategy (the document that sets out Promote Shetland's goals) is keen to single out the importance of culture and exemplifies what aspects may be drawn on: "Many of the intentions set out in the Cultural Strategy involve the nurturing of the things that make Shetland special, for example the dialect, the environment and the craft traditions" (Promote Shetland 2011). ${ }^{7}$ Yet with regard to "the dialect," several documents make it clear that, while central to the uniqueness of Shetland and its brand, it remains optional for potential residents. For example, the following text is an extract from the documents provided to newcomers by the Shetland Brand and reproduced in a recent publication: "The Shetland dialect has a Scots foundation, but many words and turns of phrase from Old Norse are embedded in it, so that with Shetland accents it can sound very strange - possibly a bit like Dutch or Germanto the inexperienced ear. . . It's worth stressing, incidentally, that Shetlanders make a point of switching into pure English if they think someone won't understand the dialect."

In other words, even though the branding strategy consists in exoticizing the islands through emphasizing their Norseness, it also highlights the idea that Shetland, despite being "other," is only marginally so. In order to remain attractive, the archipelago must be firmly grounded in international, Anglophone markets, and newcomers must be reassured that no linguistic effort will be re-

7. This refers to a 2009 document titled On the Cusp ... Shetland's Cultural Strategy: A Vision for Cultural Life in Shetland 2009-2013, published by the Shetland Community Planning Board.

8. "Ten Reasons to Move to Shetland": http://move.shetland.org/10-reasons-to-move-to-shetland-v1-0.pdf. 
quired, as locals will adapt to them - arguably a feature of the prevailing linguistic regime of "dialect." This first process thus echoes Nakassis's analysis of brand as "a mix of sameness and difference" (Nakassis 2012, 625): language in Shetland is an optional element that anyone, irrespective of their origin, can tap into to accentuate authenticity and rootedness (of a business, a product) without any constraints.

The use of dialect serves for distinction purposes that, along with other markers such as traditional knitting, might help develop a niche dimension. Dialect is made useful, in other words, by accentuating its dialectal status: "dialect" is no longer a glossonym but a reservoir of signs - mainly words - that one can easily use for a variety of authenticating purposes. The most emblematic of those terms is probably peerie (small), often used on signage, in business branding, and more generally as a common index of Shetlandness.

The second strategy draws on a similar principle as well as on the universal availability of distinction through authenticity for anyone living in Shetland, whether of older Shetland stock or recently arrived. This strategy redefines Shetland's distinctiveness not as the product of its people or of its contemporary culture, but as the result of its past association with Norway and Denmark. What makes Shetland distinctive is its Norse heritage, best preserved in its landscape through place names in particular - the focus of much attention in the Shetland Brand strategy. Place names are, for instance, the object of a brochure produced by the Shetland Amenity Trust that emphasizes Scandinavian connections:

Shetland's place names reflect our strong Norse heritage, with subsequent Scottish and English influences. Settlers from Norway arrived around $800 \mathrm{AD}$ onwards, bringing with them a vast repository of highly descriptive words suitable for naming every feature of the landscape (both natural and manmade) as well as a stock of actual place names that were in use in Western Norway. Their names replaced those used by earlier settlers.

The language they used was Old Norse (or West Norse), from which Norwegian, Faroese and Icelandic are derived. In Shetland and Orkney, a language called Norn developed and was spoken until the seventeenth century.

The focus on Scandinavianness frames Shetland as Scandinavia-in-Britain, enabling the islands to occupy a unique segment on the tourism market and to enhance strategies of distinction on the part of local businesses. 
Nordicness, however, is ubiquitous, but always amicably so. The "Ten Reasons to Move to Shetland" document thus states:

The law, education, commerce, faith and quite a lot of our architecture are all essentially Scottish. People here cheer on Scottish or English football teams, follow events in Ambridge or Albert Square, or listen to Katie Melua or Nicola Benedetti on their iPods.

However, there's much that is less familiar. The first clue that Shetland is somewhere apart comes from road signs that point to places with names like Cullivoe or Weisdale. Look at a map of the islands and it gets even stranger. Places exist, often where no one lives, with names like Swartahoull and Winyadepla. These place names all have their roots in Old Norse.

Then there are some of the waterfront buildings and newer housing, which unmistakably evoke Norway. The smaller boats, too, have a decidedly Scandinavian shape and our music is similarly influenced. ${ }^{9}$

Language is thus an important source for the construction of Scandinavianness both insofar as the dialect contains remnants of Norn and because of how place names embody this past heritage. In the process of branding Shetland there is therefore a constant search for balance between the known and the unknown, the familiar and the exotic. One can live in Shetland as one might anywhere else (Ambridge is the imaginary setting of the well-known BBC radio program The Archers; Albert Square is the fictional location of Eastenders, a BBC television soap opera) while still indulging in and taking advantage of the unique connections drawn from Shetland's heritage.

Language is made available to newcomers through a frame of Nordicness in a way that removes authenticity from people and reframes it as tied to heritage, scenery and place. Language is at best iconic in this strategy, but as an index of Scandinavianness it defines the niche that businesses in Shetland should aim for: Scandinavia in Britain. Language is an essential component of a strategy that implies narrating the Scandinavian (linguistic) past of the islands, however tokenistic its use.

This strategy is not in itself particularly original. What does, however, make it unusual is the context of demographic crisis in which it is implemented. The challenge is therefore to craft a discourse of authenticity both steeped in tradition and available to all. In a society where the vernacular is still very much

9. Ibid. This document features the successor organization to the Shetland Brand, Promote Shetland. 
spoken and a part of the cultural elements that define the islands as authentic (in the words of the branding initiative), this entails first creating a balance between the exotic and the familiar: people speak dialect, but they will switch to English, and not just to any English but to a pure one, ensuring participation on global international and Anglophone markets. Second, it locates the source of authenticity in a remote past that anyone can appropriate, including locals as well as - and this is paramount-newcomers with no previous associations with the islands.

\section{More Irish than Ireland: The Promotion of Irish as a Branding Tool in the Wake of Economic Crisis}

In 2010, the Republic of Ireland was mired in the depths of a severe economic recession precipitated by the 2008 global financial crisis and subsequent domestic banking crisis and property bubble eruption (Maître, Russell, and Whelan 2014, 1). "Deeper and longer than almost any other in the industrialized world" (McDonough et al. 2010), the Irish recession generated soaring unemployment rates, increased levels of long-term unemployment and "a particularly negative impact on the market for finance" on which Ireland's small and medium sized enterprises (SMEs) heavily relied (InterTradeIreland 2013, 9). It was in 2010, however, that Baile Rua le Gaeilge (Ballyroe with Irish), a local community language development association, won a substantial grant from a national Irish-language organization - a grant that allowed them to pursue their long-gestating but previously unfunded plan of promoting the use of the Irish language within their local business community in Ballyroe, Ireland.

Established in the early 2000s and tasked with the overarching objective of increasing the use of Irish as a community language in their local area, Baile Rua le Gaeilge (BRG) had in their early years worked to achieve this goal through an array of activities that focused on two key domains in which Irish had traditionally been construed as essential: education (Irish language classes for children and adults, conversation groups, summer camps) and culture (Irish language competitions for children, school drama productions, festivals). The private sector, however, had always proved a more difficult target for their work: as Eoin, the development officer of the organization, related during our first meeting in 2014, "we were happy with our results in terms of education, culturally with festivals, helping out with classes, and we always had good attendance, but in terms of impact on business it's very hard."

Even without the backdrop of Ireland's economic collapse, BRG would have faced challenges in promoting the Irish language in Ballyroe in general and in 
business in particular. Ranking among the top twenty largest urban areas in the Republic of Ireland, Ballyroe is situated in the west of the country but has consistently lain outside the boundaries of the Gaeltacht - the governmentdelimited, geographically defined Irish-speaking areas of the Republic, mostly located in the west - since the original demarcation of these regions in 1926. Officially, the percentage of Ballyroe's population that self-reported using the Irish language daily outside the education system in the 2011 national census was slightly under the 1.8 percent that obtained across the Republic as a whole (Central Statistics Office 2012). Anecdotally, when asked about the use of Irish in town, almost every local resident interviewed during ethnographic fieldwork in Ballyroe in 2014 and 2015 recommended going elsewhere to find the language being used-and specifically to Gaeltacht areas, reflecting a longstanding belief in Ireland that the "real" Irish language and its "authentic" native speakers can only be found in these regions (see O’Rourke 2011; Ó hIfernáin 2015).

Moreover, as described by Maguire (1991, 13) and Walsh (2011, 338-339), English has for centuries dominated in Irish cities and towns as the language of economic and social advancement, especially as Irish came to be more and more associated with rural, impoverished, and peripheral settings after the onset of processes of industrialization and urbanization in Ireland (Maguire 1991, quoted in Walsh 2011, 339). The Irish private sector has therefore long been an Anglophone space, as English has historically dominated Irish as the language of prestige, social mobility, and participation in international employment markets (Ó Laoire 2008, 258).

Baile Rua le Gaeilge thus faced the compounded challenge of promoting the Irish language in an urban non-Gaeltacht area, in the traditionally Anglophone private sector, and within the overarching context of the worst economic downturn in the modern history of Ireland. As the following sections will detail, the members of BRG responded to this challenge by developing new strategies designed to shift the metasemiotic frames through which the value of Irish was understood in such a way as to appeal specifically to their local business community. Drawing on widely circulating discourses on the economic value of language and the Irish language in particular, these new strategies sought to convince local businesses that the language could be lucratively mobilized as a sign in the place branding of Ballyroe, as well as in the branding of their own businesses. Moreover, BRG positioned Irish and its branding capacity as a contributing factor in Ballyroe's recovery from the post-2008 recession afflicting the members of their local business community, thereby reframing the language not 
only as an available resource but as a crucial element of an economic approach to addressing an economic crisis.

Before exploring these processes, however, it is necessary to understand how the role of Irish in the Ballyroe place brand articulated with the nation branding of the Republic of Ireland as a whole. This relationship will be the object of the next section.

\section{Brand (Anglophone) Ireland}

As recognized throughout the literature on place - and more specifically, nation-branding (e.g., Morgan, Pritchard, and Pride 2002; Anholt 2007; Aronczyk 2013), Ireland has been — or at least was, before the 2008 financial crisis and the ensuing recession-widely regarded as a success story. This acclaim, as nation-branding guru Simon Anholt has observed, was largely generated by the attention paid worldwide to Ireland's transformation "from a collapsing rural backwater in the 1960s" to the economic miracle of the Celtic Tiger (Anholt 2007, 47). It should be noted that the cultivation of "Brand Ireland" long predates the emergence of nation branding as a key element of the globalized new economy (see, e.g., Clancy 2009; Patterson 2009; Fanning 2011): "Brand Ireland," remarked Anthony Patterson, can be seen as having been "born out of Ireland's struggle to be unlike England" (2009). Since the 1950s, however, the management of the Republic of Ireland's national brand has effectively fallen within the purview of two authorities: IDA Ireland (established in 1949), the government agency responsible for Ireland's industrial development and particularly for attracting foreign direct investment (FDI), and Fáilte Ireland (from 2003 - successor of Bord Fáilte Éireann, established in 1955), the National Tourism Development Authority of the Republic (Fanning 2011). The nation branding of Ireland has thus been associated with two of the most essential components of the Irish economy: while FDI accounted for 22.9 percent of Ireland's GDP in 2013 (World Bank 2014), that same year saw international tourism contribute over $€ 4$ billion to the Irish economy (Irish Tourist Industry Confederation 2013). In light of the central importance to the Irish economy of sectors related to nation branding, it is perhaps unsurprising that Patterson has observed that "Irish national prosperity is so intrinsically linked to the ethereal edifice that is Brand Ireland" $(2009,89)$.

The role of the Irish language in the "ethereal edifice" of Brand Ireland, however, is far from intrinsic. Although the Irish language is officially the only national and first official language of the Republic and might therefore rank among the signs on which the agents of nation branding in Ireland could draw, 
this does not appear to be the case. While certain nation-states mobilize multilingualism to construct their uniqueness and attractiveness as "more appropriate and legitimate place[s] to do business" (Duchêne and Del Percio 2014, 78), economists such as Frank Barry (2007) have noted that Ireland's reputation as an English-speaking country has constituted one of the key contributing factors of the country's success in attracting foreign direct investment, particularly from the United States. Tasked with drawing further FDI to Ireland, IDA Ireland stresses the Anglophone nature of Ireland and its workforce. The agency's "Why Ireland?" fact sheet addressed to potential investors, for instance, leads with the statement that "Ireland is the only English speaking country in the Eurozone," and English appears further down the sheet as one of the three E's (along with "Education" and "Ease of doing business") that contribute to making Ireland "the best place in the world to do business" (IDA Ireland, 2015). ${ }^{10}$ Similarly, while materials produced by Fáilte Ireland may occasionally reference the Irish language as an element of Ireland's cultural heritage, the agency actively promotes and supports the development of the English Language Leaning sector in Ireland, with an emphasis on attracting overseas students to the country's English as a foreign language programs. The elite institutions shaping the strategically selective national imaginary projected by Brand Ireland thus appear to have largely excluded Irish from the signs that comprise this brand.

It is this near-total erasure of Irish at the national level of branding, however, that renders the language useful to Baile Rua le Gaeilge's business-focused initiative. As the next section will detail, the organization indeed takes advantage of the Anglophone Brand Ireland to position Irish as a key element of differentiation on tourist and visitor markets both domestic and international.

\section{Money Talks: Speaking the Language of Branding}

\section{to Promote Irish in Business in Ballyroe}

Recognizing what they perceived as the disadvantaged position of Irish as capital on the linguistic market of their local private sector, the staff of BRG were convinced that they would need to adapt their discourses in approaching the business community as a new domain of their promotion. ${ }^{11}$ This adaptation,

10. See http://www.idaireland.com/how-we-help/resources/infographics/why-invest-in-ireland/.

11. The promotion of minority languages within the business sphere is of course only new in relation to Ballyroe. Irish is promoted as an economic resource for business in a few other urban areas in both the Republic and Northern Ireland, and such initiatives are also well documented in a range of other European minority language contexts including Wales, Scotland, and the Basque country. 
as this section will detail, relied heavily on establishing a link between the Irish language and the valuable branding of local businesses, which in turn was positioned as contributing to an overall enhancement of the place brand of Ballyroe itself.

In describing the genesis of the BRG's work with the business community, Mícheál, the chief architect of the initiative, explained the need for a rethinking of the organization's strategies to suit the commercial sphere, relating that they had begun from the starting assumption that "when you're approaching business people, you have to approach them from a business point of view." The new initiative therefore had to be "business-driven," which — as in Shetland-meant downplaying the threat that the language advocacy element potentially represented to profit margins: as Mícheál put it, "there was no use ... in approaching it and saying to business people that we wanted to do this because of language promotion or anything else-there had to be a business element, and that had to be the driving force." The staff of BRG thus sought to articulate their business-oriented initiative with what they believed to be the values of the local business community, thereby foregrounding an indexical alignment of the value of Irish with economic benefit rather than with national pride or linguistic rights.

This strategic realignment of the metasemiotic framing of the value of Irish is made clear in the literature distributed by the organization as part of their shift into working with the private sector. Rather than using their existing materials, BRG commissioned the designing of a new logo and set of supporting flyers, posters, and so on, specifically for their business initiative. The graphics of the logo were meant to represent "smiley money," in the words of Mícheál, and all the posters and informational packets distributed throughout the business community featured photos of the main streets of Ballyroe bustling with paying customers, thereby ideally conjuring an indexical link between the Irish language and economic prosperity. Beyond the design, the content of the materials strengthened the reframing of Irish in terms of economic benefit to businesses. In their pamphlet introducing the initiative, for example, BRG foreground market considerations and start off by asking business owners the following list of questions: "Would you like to . . . Raise your product profile? Attract more customers? Devise a new marketing strategy? Develop a unique Brand/Identity? Increase your profit shares?"

Referencing how "recent times have seen the practice of bilingualism become increasingly popular in both the public and private sectors," another brochure positions Irish as a "practical and productive business tool" and em- 
phasizes that, together with English, "the unique characteristics of the Irish language are being effectively harnessed by the Business Community as a marketing tool on signage, stationery, packaging and advertisements." With this emphasis on the "recent popularity" of bilingualism as a business tool, these materials firmly position the Irish and its value within the framework of now widely circulating discourses concerning languages - and minority languages in particular - as resources in the globalized new economy (Duchêne and Heller 2012).

This promotion of Irish as a resource for the branding of individual businesses and products was an important element in BRG's new initiative. However, they also sought to establish an overarching discourse designed to position Irish as a valuable resource for the entire private sector of Ballyroe-as well as for the town's wider community. Having reframed Irish as a "practical and productive" marketing and business tool and a source of "increased profit shares," the organization needed to identify a source for the economic benefits associated with Irish, and for this they turned to contributions the language could make to the place branding of Ballyroe.

Capitalizing on the relative absence of Irish at the national branding level, Baile Rua le Gaeilge sought to position the presence of the language in the businesses of the town's commercial center as a strategic branding element for Ballyroe. In its coverage of the launch of the business-focused initiative, a local newspaper reported that Mícheál first pitched Irish to the private sector by highlighting that "tourists come to Ireland to savour the Irish culture and this is about promoting that culture along with raising product profiles, attracting more customers and developing our unique [Ballyroe] brand.” As a strategically coordinated sign of Irish culture, a commercial landscape accented with Irish would ideally render the town of Ballyroe more traditionally Irish than the rest of Ireland, thereby differentiating it from the other urban areas in the country and making it more "savory" to tourists seeking out authentic Irish culture. Explaining how the promoted presence of Irish in local businesses would further differentiate Ballyroe from other towns as a "traditional" destination, Eoin related during our interview that "even though Killarney is very close to the Kerry Gaeltacht, it's a town that you wouldn't describe as traditional," whereas "if you really want a real taste of traditional Ireland, . . . really [Ballyroe's county] is the best county in Ireland, without a doubt." Already the principal town of the "best" traditional county in Ireland, Ballyroe would stand out even more as a domestic and international destination with a commercial center as Gaeilge (in Irish). 
Furthermore, the organization deliberately sought to link the private sector's use of Irish to the existing tourism image of Ballyroe in order to make clear how the language - which might not necessarily be accepted as a standalone branding component for the non-Gaeltacht town-would complement the town's established brand. As Mícheál explained, BRG approached their new initiative by asking themselves, "How are you going to get [commercial Irish] to sit in the environment it's going to sit in?" In response to this question, Mícheál related that they recognized that "the key aspects would be that [Ballyroe] would be regarded as the heartland of traditional Irish music, song and dance." It was then important, in his words, to focus on linking Irish with these elements of "the intrinsic and the indigenous culture of the town"; in this way, the strategy ensured that the use of Irish in business was "sitting comfortably side-by-side with everything else, so it was not being done in isolation." The promotional pamphlet that BRG distributed to the local business community thus emphasized that the use of Irish in business would further enhance the recognized reputation of the town, explaining that commercial Irish would "raise the local and national profile of [Ballyroe] as a centre of excellence in promotion of traditional culture including music, dance and language, making it a more attractive visitor destination." By aligning Irish with the key signs of the existing "Ballyroe Brand," the initiative positioned the language as integral to the town's tourist draw while avoiding the risk of requiring Ballyroe to be rebranded as an Irish-language destination - and thus potentially calling on members of the local business community to "live the brand" by speaking Irish.

Money, However, Does Not Speak Irish: Promoting a Profitable, Accessible, and Visual Irish

This last observation speaks to an overarching strategy mobilized by BRG in their business-focused initiative: the lack of emphasis on speaking Irish. Through their promotional materials and activities, the organization prioritizes the visual integration of Irish into local businesses over the incorporation of spoken Irish into service provision. As cited earlier, their brochure emphasizes the branding potential of the "unique characteristics" of Irish on "signage, stationery, packaging and advertisements." One of BRG's regular activities is to provide personalized bilingual or Irish-only posters to businesses to display in their shops for holidays such as Christmas and St. Patrick's Day, and the organization celebrated this latter holiday in 2015 by coordinating a shop window competition in which local businesses were encouraged to as- 
semble displays that visually incorporated the language. The promotion of Irish as a means of oral communication, meanwhile, is largely downplayed: BRG's advocacy of spoken Irish is mostly limited to the provision of sheets and cards listing Irish words and phrases, their phonetic transcriptions, and their English definitions. These materials aim to encourage business owners and employees to try using a few words of Irish when interacting with their customers, and indeed at least two local proprietors kept them by the cash register for easy reference. They are not, however, designed to support a full commercial interaction in Irish beyond the exchange of greetings or pleasantries.

The visual orientation of BRG's business-oriented initiative reflects two strategic considerations: inclusivity and cost. With its overarching focus on community-wide language development in an area not known for using Irish as a community language, the organization seeks to render the initiative accessible to any member of the private sector, regardless of linguistic proficiency in Irish. As stated in their brochure, the organization "strongly believe[s] that the Irish language can be a great advantage to every type of business in various ways, even if you don't have fluent Irish!" At the same time, the emphasis on the visual use of Irish limits investment (financial, temporal, etc.) in the language to incorporating Irish when (re)designing signage, menus, stationery, and so on, or to hanging the free Irish or bilingual signs printed by the organization - and therefore effectively nullifies more costly considerations such as language training or the hiring of Irish-speaking staff. As is the case with the Shetland Brand's management of Shetlandic, BRG's business-centered initiative thus primarily promotes the Irish language for something other than its referential function. What is highlighted is the capacity of the visual presence of the language to index the traditional Irish culture that lends lucrative distinction to the brand of (largely non-Irish-speaking) Ballyroe on (almost entirely non-Irish-speaking) international and domestic tourist markets.

More than merely promoting visual Irish as one of many available signs for enhancing the Ballyroe Brand, however, BRG chose to invest the use of Irish by local businesses with particularly charged meaning in light of the wider conditions impacting the town and Ireland as a whole at the time of the initiative's launch-namely, the post-2008 economic crisis.

(Re)branding in Conditions of Crisis: Commercial Irish as Driver of Economic Regeneration

Introducing their new business-focused initiative in the early 2010s, Baile Rua le Gaeilge realized the necessity of adjusting their discourses not just to the 
Anglophone urban business sphere in general but to the private sector of their local town in the midst of Ireland's severe economic recession following the 2008 financial crisis. The Irish recession had by the early 2010 s generated a nationwide unemployment rate of 19 percent, with the average for Ballyroe falling just under that figure (Central Statistics Office 2012). Annual reports issued by Ballyroe's county authority between 2008 and 2012 noted the negative impact of the recession on development, economic activity, employment, income level, and the delivery of public services in the local area. Business closures and personnel redundancies were regular features in the regional newspapers from this period, and fieldwork interviews with the proprietors of locally owned and run businesses - traditionally the majority of the private sector in Ballyroe - revealed the prolonged hardships endured by owners of small independent businesses in the area.

Against this backdrop of the nationwide economic climate and the struggles of local businesses in particular, BRG recognized the need to assign further meaning to Irish as a business resource. The language would not only be promoted to the private sector in a "business-driven" way as one possible mobilizable sign for branding, but would furthermore be positioned as a key contributor to Ballyroe's economic recovery. Irish would in effect be sold as a way to brand individual businesses and in turn the entire visually "Irishized" town, in a move that would ideally give Ballyroe a competitive advantage over other towns in Ireland in a context of increased competition for a rarer resource: customers. Mícheál thus explained that the initiative was designed to promote the use of Irish in the private sector as a means of "redress[ing] the economic turndown" that would constitute part of the "regeneration" of the local economy - a local economy desperately in need of the bustling crowds of consumers pictured on the initiative's promotional materials. His words echoed an article from the local paper's coverage of the launch of the businessfocused initiative, in which Mícheál is quoted as explaining that the use of Irish in business "could ultimately raise profit shares for everybody concerned and bring some prosperity to the town." Similarly, the other main local paper in Ballyroe related in its account of the launch that BRG was "hoping" that the use of the language would "boost business" in Ballyroe. The increased tourism and visitor revenue generated by the enhanced place branding that visual Irish could provide was thus positioned as part of the answer to Ballyroe's struggle against the enduring recession.

Within the context of this reframing of the commercial use of Irish as an element of economic recovery, existing activities organized by Baile Rua le 
Gaeilge were also repositioned as sources of financial benefit for the local business community. The organization, for example, had for several years organized Irish-language conversation circles for Ballyroe's Irish speakers and learners, hosting them first in their own offices and then moving them into local cafés and restaurants to increase their visibility and the opportunities for people to take part. Such conversation circles are a common activity in the repertoires of contemporary Irish-language advocacy organizations and are designed to provide an informal, "judgment-free" environment in which Irish speakers of all levels can feel comfortable conversing with any degree of competence. Drawn into the organization's business-oriented initiative during Ireland's recession, however, the hosting of a meeting of the conversation circle was represented as an opportunity for a local establishment to raise their bottom line. As related by Eoin, after the onset of the economic recession cafés and restaurants were "far more open" to the pitch that "well look, we can bring 10 or 20 people in here every now and then, they'll spend a few bob," with the owners eager to host the conversation circle because it was "money that [they] wouldn't have" otherwise. While the conversation circle had started with eight participating cafés, Eoin later recounted, after the onset of the economic downturn the other café and restaurant owners of Ballyroe started asking the organization "well why aren't you coming to us?" With "positiv[ity] in terms of their outlook to Irish," and not any required level of visual integration of the language or service provision in Irish, set as the criterion for hosting the conversation circles, the roster for a four-month period of weekly meetings had swelled to twenty-two host establishments by the winter of 2014. Following the logic of BRG's discourses, the willingness of owners of cafés and restaurants to host conversation circles and to perhaps (though not necessarily) encourage their staff to use whatever Irish they may have with the participants would in turn further solidify the traditionally Irish brand of Ballyroe. This could thus, critically, generate more revenue for the individual businesses and the town as a whole in the midst of the community's struggles with the economic recession.

This final example from Eoin illustrates well the assignment of new meanings to the Irish language and its promotion in business within the metasemiotic framework mobilized by Baile Rua le Gaeilge to promote Irish as a resource to their local, recession-burdened business community. In reframing activities such as the visual integration of Irish or the hosting of Irish-language conversation circles in terms of boosting bottom lines and enhancing the overall place brand of Ballyroe, the organization positioned the language as a se- 
miotic reservoir that could be tapped into in order to drive the regeneration of the local economy and to strengthen the differentiated positioning of Ballyroe on tourist markets both domestic and international. Though the value of Irish as a communicative means may be downplayed, the business-focused initiative of Baile Rua le Gaeilge (re)invests the visual language as an iconized sign with value as an economic solution to an enduring economic crisis.

\section{Conclusion}

In both Shetland and the west of Ireland, situations interpreted as crises (demographic or economic) are used as triggers to justify a shift in the metasemiotic frames through which language is conceptualized. In both cases the ornamental aspects of language are brought to the fore in order to make Shetlandic and Irish available to a larger pool of potential users, in particular to businesses. In Shetland, the Scandinavian aspects of Shetlandic are reframed as a way to channel the authenticity that visitors are thought to be looking forin the form of indexical links with the land. Language, in that sense, acts as one potential way to achieve distinction with regard to the rest of Scotland. In Western Ireland, Irish is presented by language advocates as one way of addressing the cataclysmic economic downturn of 2008. But as in Shetland, this entails foregrounding the role of Irish as linguistic decoration rather than as a means of communication and situating the value of the language in the differentiation its visual form can impart on a given place. Through these processes of semiotic reordering, the authentic (and therefore valuable) heritage indexed by each language becomes primarily associated with places rather than with speakers, thereby potentially rendering these signs available for branding purposes to any social actors living or working in - or moving to, as the case may be-Shetland or Ballyroe. With the branding potential of these languages then positioned as part of the solutions to crises, this indexical realignment exemplifies the neoliberal metasemiotic framework through which all elements of social and cultural life may be strategically made marketable - in this case on the intra- and international markets on which people themselves are vied for.

In investigating these situated realizations of the semiotic reframing of language as an economically valuable resource for place branding, we have only begun to examine the consequences of this increasingly widespread process. Although such a reframing is positioned as a solution to crises in Shetland and Ballyroe, it in turn has the potential to generate other tensions. In Ballyroe, for example, the promotion of Irish as a primarily visual marketing resource rep- 
resents a deviation from the traditional objective of language policy and language advocacy in Ireland, which have traditionally sought to work toward the restoration of Irish as a spoken community language. Traces of tensions around the visual orientation of the initiative have indeed already been encountered in Ballyroe, where several local residents - who were mostly also more fluent or active speakers of Irish - expressed cynicism about Irish being integrated on shop fronts while no one inside could actually converse in the language. There are thus ample grounds on which to expand our examination of the role of the metasemiotic reframing of language as a branding element in both the resolution and creation of crises as neoliberal regimes continue to encroach on new domains of social and cultural life.

\section{References}

Abrams, Lynn. 2005. Myth and Materiality in a Woman's World: Shetland 1800-2000. Manchester: Manchester University Press.

Anderson, Elizabeth, Ali Bakir, and Eugenia Wickens. 2015. "Rural Tourism Development in Connemara, Ireland." Tourism Planning and Development 12 (1): 73-86.

Anholt, Simon. 2007. Competitive Identity: The New Brand Management for Nations, Cities and Regions. Basingstoke: Palgrave MacMillan.

Aronczyk, Melissa. 2013. Branding the Nation: The Global Business of National Identity. Oxford: Oxford University Press.

Barnes, Michael P. 1998. The Norn Language of Orkney and Shetland. Lerwick: Shetland Times.

Barry, Frank. 2007. "Third-Level Education, Foreign Direct Investment and Economic Boom in Ireland." International Journal of Technology Management 38 (3): 198-219.

Blommaert, Jan. 2007. "Sociolinguistic Scales." Intercultural Pragmatics 4 (1): 1-19.

Bourdieu, Pierre. 1982. "Les rites comme actes d'institution." Actes de La Recherche en Sciences Sociales 43 (1): 58-63.

Brennan, Sara, and James Costa. 2013. "Celtic Commodified: The Role of Minority Languages in Scottish and Irish National Celebrations." Babel Civilisations 27 (8): 87-104.

Central Statistics Office. 2012. "This Is Ireland: Highlight from Census 2011, Part 1.” Report. Central Statistics Office, Dublin.

Christie-Johnston, Alastair, and Adaline Christie-Johnston. 2010. Shetland Words. Lerwick: Shetland Times.

Clancy, Michael. 2009. Brand New Ireland? Tourism, Development and National Identity in the Irish Republic. Farnham: Ashgate.

Cohen, Bronwen J. 1983. "Norse Imagery in Shetland: An Historical Study of Intellectuals and Their Use of the Past in the Construction of Shetland's Identity, with Particular Reference to the Period 1800-1914." PhD thesis, University of Manchester.

Crawford, Barbara E. 1969. "The Pawning of Orkney and Shetland." Scottish Historical Review 48 (145): 35-53. 
Del Percio, Alfonso. 2013. "Capitalizing on National Diversity: Modern Ideologies of Multilingual Switzerland and the Regimentation of the Nation's Promotion under Late Capitalism." PhD thesis, University of St. Gallen.

Duchêne, Alexandre, and Alfonso Del Percio. 2014. "The Economic Capitalization on Linguistic Diversity: Swiss Multilingualism as a National Profit?” In Multilingual Encounters in Europe's Institutional Spaces, ed. Johann W. Unger, Michal Krzyzanowski, and Ruth Wodak. London: Bloomsbury Academic.

Duchêne, Alexandre, and Monica Heller, eds. 2012. Language in Late Capitalism: Pride and Profit. London: Routledge.

Dzenovska, Dace. 2005. "Remaking the Nation of Latvia: Anthropological Perspectives on Nation Branding." Place Branding 1 (2): 173-86.

Eckert, Penelope. 2008. "Variation and the Indexical Field." Journal of Sociolinguistics 12: 453-76.

Etrillard, Aude. 2015. "A Critical and Ethnographic Approach to Language Practices in Lifestyle Migrations." In Practicing the Good Life? Lifestyle Migration in Practices, ed. Kate Torkington, Inês David, and João Sardinha, 200-217. Newcastle: Cambridge Scholars.

Fanning, John. 2011. "Branding and Begorrah: The Importance of Ireland's Nation Brand Image." Irish Marketing Review 21 (1-2): 23-31.

Fournier, Susan. 1998. "Consumers and Their Brands: Developing Relationship Theory in Consumer Research." Journal of Consumer Research 24 (4): 343-73.

Gal, Susan. 2005. "Language Ideologies Compared: Metaphors and Circulations of Public and Private." Journal of Linguistic Anthropology 15 (1): 23-37.

Gorman, Catherine, and Ziene Mottiar. 2015. "Economic Recession as a Catalyst to Increased Collaboration in Rural Tourism." In Collaboration in Tourism Businesses and Destinations: A Handbook, ed. Dogan Gursoy, Melville Saayman, and Marios Sotiriadis, 141-54. Bingley: Emerald.

Graham, John J. 1979. The Shetland Dictionary. Lerwick: Shetland Times.

Grydehøj, Adam. 2008. "Branding from Above: Generic Cultural Branding in Shetland and Other Islands." Island Studies Journal 3 (2): 175-98.

Hammond, Matthew H. 2006. "Ethnicity and the Writing of Medieval Scottish History." Scottish Historical Review 85 (1): 1-27.

Harvey, David. 2005. A Brief History of Neoliberalism. Oxford: Oxford University Press.

Heller, Monica. 2008. "Repenser le plurilinguisme? Langue, postnationalisme et la nouvelle économie mondialisée." In Diversité Urbaine: 163-76.

2011. Paths to Post-nationalism: A Critical Ethnography of Language and Identity. Oxford: Oxford University Press.

InterTradeIreland. 2013. "Access to Finance for Growth for SMEs on the Island of Ireland." Report. http://www.intertradeireland.com/media/AccesstoFinancereportFINAL10.01.14 .pdf.

Irish Tourist Industry Confederation. 2013. "End of Year Review 2013 and Outlook for 2014." Report. Dublin: Irish Tourist Industry Confederation.

Kaneva, Nadia, and Delia Popescu. 2011. "National Identity Lite: Nation Branding in Postcommunist Romania and Bulgaria." International Journal of Cultural Studies 14 (2): 191207. 
Klein, Naomi. 2008. The Shock Doctrine. London: Penguin Books.

Lucarelli, Andrea, and Sara Brorström. 2013. "Problematising Place Branding Research: A Meta-theoretical Analysis of the Literature." Marketing Review 13 (1): 65-81.

Maguire, Gabrielle. 1991. Our Own Language: An Irish Initiative. Clevedon: Multilingual Matters.

Maitre, Bertrand, Helen Russell, and Christopher T. Whelan. 2014. "Economic Stress and the Great Recession in Ireland: Polarization, Individualization or 'Middle Class Squeeze'?" UCD Geary Institute Discussion Paper Series, no. WP2014/07. Geary Institute, Dublin.

McDonough, Terrence, Ray Kinsella, David Jacobson, Paul Teague, Peadar Kirby, Rob Kitchin, James Wickham, et al. 2010. "Open Letter from 28 Economists, Social Scientists and Economic Analysts.” In Stimulating Recovery, ed. Michael Burke, Ray Kinsella, and Sinéad Pentony, v-viii. Dublin: TASC.

Morgan, Nigel, Annette Pritchard, and Roger Pride, eds. 2004. Destination Branding: Creating the Unique Destination Proposition. Burlington: Elsevier.

Mortensen, Peter. 2000. “'The Descent Of Odin': Wordsworth, Scott and Southey among the Norsemen.” Romanticism 6 (2): 211-33.

Nakassis, Constantine V. 2012. "Brand, Citationality, Performativity." American Anthropologist 114 (4): 624-38.

Nihtinen, Atina L. K. 2011. Ambivalent Self-Understanding? Change, Language and Boundaries in the Shetland Islands (1970-Present). Åbo: Åbo Akademi University Press.

Ó hIfernáin, Tadhg. 2015. "La pratique de l'irlandais et la minorité irlandophone." La Bretagne Linguistique 19: 81-97.

Ó Laoire, Muiris. 2008. "Education for Participation in a Bilingual or a Multilingual Society? Challenging the Power Balance between English and Irish (Gaelic) and Other Minority Languages in Ireland." In Forging Multilingual Spaces: Integrated Perspectives on Majority and Minority Bilingual Education, ed. Christine Hélot and Anne-Marie de Mejía, 256-64. Clevedon: Multilingual Matters.

Olins, Wally. 2002. "Branding the Nation: The Historical Context." Brand Management 9 (4-5): 241-48.

O'Rourke, Bernadette. 2011. Galician and Irish in the European Context: Attitudes towards Weak and Strong Minority Languages. Basingstoke: Palgrave MacMillan.

Patterson, Anthony. 2009. "Brand Ireland." Irish Marketing Review 20 (2): 89-98.

Pietikäinen, Sari, and Helen Kelly-Holmes, ed. 2013. Multilingualism and the Periphery. Oxford: Oxford University Press.

Prahalad, C. K., and Venkat Ramaswamy. 2004. The Future of Competition: Co-creating Unique Value of Customers. Boston: Harvard Business School Press.

Prentice, Richard, and Vivien Andersen. 2000. "Evoking Ireland: Modeling Tourist Propensity." Annals of Tourism Research 27 (2): 490-516.

Promote Shetland. 2011. The Shetland Marketing Strategy. Lerwick: Shetland Islands Council. Roitman, Janet. 2013. Anti-crisis. Durham, NC: Duke University Press.

Rossiter, Ned. 2003. "Processual Media Theory." Symplokē 11 (1-2): 104-31.

Shetland Islands Council. 2012. Shetland in Statistics. Lerwick: Shetland Islands Council.

Silverstein, Michael. 2003. "Indexical Order and the Dialectics of Sociolinguistic Life." Language and Communication 23 (3-4): 193-229. 
Thomson, William P L. 1983. "Population and Depopulation." In Shetland and the Outside World, 1469-1969, ed. Donald J. Withrington, 150-89. Oxford: Oxford University Press. Urciuoli, Bonnie, and Chaise LaDousa. 2013. "Language Management/Labor." Annual Review of Anthropology 42:175-90.

van Ham, Peter. 2008. "Place Branding: The State of the Art." Annals of the American Academy of Political and Social Science 616 (1): 126-49.

Walsh, John. 2011. Contests and Contexts: The Irish Language and Ireland's Socio-economic Development. Bern: Lang.

Wieviorka, Michel. 2009. "La sociologie et la crise." Cahiers Internationaux de Sociologie 127 (2): 181-98.

World Bank. 2014. "Foreign Direct Investment, Net Inflows (\% of GDP)." Report. http:// data.worldbank.org/indicator/BX.KLT.DINV.WD.GD.ZS. 


\section{QUERIES TO THE AUTHOR}

q1. AU: Your article has been edited for grammar, clarity, consistency, and conformity to journal style. Quotes of fewer than 100 words are generally not set as displayed reductions but in the paragraph. Please read the proof carefully to make sure that your meaning has been retained. Please note that in order to accommodate the second level heads immediately below (Branding the Nation ... , and Research Sites and Fieldwork), I promoted the first subhead, "Crises and Neoliberalism" to a level-one head. Is this acceptable, or is there another header you'd like to use?

q2. AU: May we assume italics for emphasis to be in the original text quoted? Otherwise, journal style discourages italics, and these should be struck if possible.

q3. AU: OK to restore what I assumed to be a capital "I" in "In" at the beginning of this quote? We can lowercase it if necessary, but the quote seems to stand alone; there is no syntactical connection to the rest of the sentence.

q4. AU: I have lowercased and enclosed in quotes "others," for consistency with how you treat this special usage later in the text.

q5. AU: Please provide a reference for the Manson citation in n. 3.

q6. AU: Based on the spelling in the main text, I have corrected the spelling in the footnote to Shetland Forwirds.

q7. AU: Is this the Liberal party (and hence a proper noun)?

q8. AU: Is March 12, 2013 correct?

q9. AU: OK to specify Geary Institute, Dublin for the Maitre et al. 2014 reference?

q10. AU: Following Press style, the names of organizations, even when in foreign languages, are not italicized.

q11. AU: For relating the details of meetings and interviews, would you care to provide dates and locations that can be noted in footnotes (say, for each new paragraph, or each new speaker)? May we assume that all quotations without attributions

q12. AU: Are these quotes clearly sourced somewhere in the text? I cannot determine which reference applies. 
q13. AU: Source?

q14. AU: The Heller seems incomplete. Is "Diversit” a published volume? If so, please provide additional details, such as author/editor, city, publisher.

q15. AU: For the InterTradeIreland citation, OK that I have deleted the place name Newry? I have added "Report" here.

q16. AU: Is the End of Year Review a report? A separately published pamphlet? I have provisionally added "Report."

q17. AU: Please provide an in-text citation for Olins 2002 or permit us to delete the ref. list entry.

q18. AU: Please provide an in-text citation for Prentice and Andersen 2000 or permit us to delete the ref. list entry. 